\title{
UPAYA-UPAYA PENINGKATAN PEMAHAMAN DAN KESADARAN PENCIPTA KARYA SENI TRADISIONAL TERHADAP HAK CIPTANYA
}

\author{
Nina Yolanda \\ Fakultas Hukum Universitas Palembang \\ Email: ninayolanda51@yahoo.com
}

\begin{abstract}
The research objective is to describe and analyze efforts to increase the understanding and awareness of the creators of traditional art works on their copyright. Writing method uses normative juridical method. Research results: efforts to increase understanding and awareness of creators of their copyright are carried out through efforts to promote intellectual property rights such as counseling, discussions, seminars, workshops, symposiums, intellectual property education and training and institutionally established a Copyright Council. In the end, it was suggested that arrangements regarding copyright law protection, especially the copyright of traditional artworks, need to be accompanied by consistent law enforcement and efforts to increase understanding and awareness of creators of their copyright needs to be intensified both in terms of quality and quantity.
\end{abstract}

Keywords: Enhancement and understanding; creator; traditional artwork dan kesadaran pencipta karya seni tradisionil terhadap hak ciptanya. Metode Penulisan menggunakan metode yuridis normatif. Hasil penelitian : upaya peningkatan pemahaman dan kesadaran pencipta atas hak ciptanya dilakukan melalui upaya sosialisasi HAKI seperti penyuluhan, diskusi, seminar, lokakarya, simposium, pendidikan dan pelatihan HAKI serta secara kelembagaan pemerintah telah membentuk Dewan Hak Cipta. Pada akhirnya disarankan agar pengaturan mengenai perlindungan hukum hak cipta khususnya hak cipta karya seni tradisional perlu diiringi penegakan hukum yang konsisten dan upaya peningkatan pemahaman dan kesadaran pencipta atas hak ciptanya perlu lebih diintensifkan baik dari segi kualitas maupun kuantitas.

Kata kunci: Peningkatan dan pemahaman; pencipta; Karya seni tradisionil

\section{PENDAHULUAN}

\section{A. Pendahuluan}

Indonesia dengan beragam suku bangsa kaya akan hasil seni tradisional yang mempunyai nilai estetika yang tinggi seperti batik tradisional Solo, seni ukir Suku Asmat, kerajinan patung Bali, dan masih banyak lainnya. Karya seni tradisional ini selain memiliki nilai seni dan estetika juga memiliki nilai ekonomis serta yang sering tidak diketahui bahwa di dalamnya terkandung hak cipta yang dilindungi undang-undang. Sangat ironis bahwa banyak pencipta yang tidak memahami bahwa ia memiliki hak cipta atas karya cipta yang dihasilkan.
Kebanyakan pencipta cukup puas jika karya ciptanya disukai banyak orang dan laku dijual, tanpa mengetahui dan memikirkan bahwa pencipta memiliki hak cipta yang perlu dilindungi dari eksploitasi secara ilegal oleh pihak yang tidak berhak. Sebagai ilustrasi dapat diuraikan tentang kejadian di Bali dimana ada turis Belanda yang memesan kerajinan patung kayu Bali ke pencipta kerajinan kayu tersebut dalam jumlah besar untuk dikirim ke Belanda. Pencipta tersebut merasa bangga karena karyanya disenangi, ia dapat uang banyak dan bangga hasil karyanya bisa diekspor ke luar negeri. Ternyata di Belanda hasil kerajinan tersebut 
didaftarkan dan pada produk kerajinan tersebut ditempelkan made in Belanda.

Tentunya eksploitasi semacam ini tidak kita inginkan karena sangat ironis bahwa pencipta yang sesungguhnya tidak mendapatkan hak yang selayaknya menjadi miliknya secara optimal, padahal pencipta inilah yang telah berkorban baik waktu, tenaga pikiran maupun materi untuk menghasilkan ciptaannya.

Kalau kita telaah dalam sistem peraturan perundang-undangan, karya seni tradisional sebagai suatu ciptaan masuk dalam lingkup perlindungan hak cipta. Dalam Undang-undang Hak Cipta No. 19 Tahun 2002 (selanjutnya disebut UUHC 2002) disebutkan ciptaan yang dilindungi adalah ciptaan yang merupakan hasil karya pencipta dalam bentuk yang khas dan menunjukkan keasliannya dalam bidang ilmu pengetahuan, seni dan sastra. Juga disebutkan bahwa pencipta yang menghasilkan ciptaan yang orisinil mempunyai hak cipta yaitu hak untuk memperbanyak dan mengumumkan ciptaannya.

Permasalahan yang muncul adalah mengenai pembuktian bahwa pencipta karya seni tradisional merupakan pencipta yang sesungguhnya. Hal ini disebabkan karena dalam sistem hak cipta pendaftaran tidak bersifat wajib dan bukan merupakan pengakuan mengenai lahirnya hak cipta, sehingga banyak pencipta tidak mendaftarkan ciptaannya yang dampaknya bisa mempersulit pembuktian secara formal jika timbul sengketa di kemudian hari.

Permasalahan lain yang muncul adalah dalam masyarakat tradisional yang mempunyai sifat komunal biasanya ciptaan yang telah dihasilkan seseorang akan dimanfaatkan secara kolektif oleh anggota masyarakat yang lain, sehingga pencipta yang sesungguhnya kurang dapat menikmati hak ciptanya secara eksklusif atau bahkan ciptaannya itu disalahgunakan oleh anggota masyarakat untuk keuntungan pribadinya.

\section{B. Permasalahan}

Terlihat dari uraian diatas bahwa pokok permasalahan adalah tingkat pemahaman dan kesadaran pencipta atas hak ciptanya masih sangat rendah, sehingga menimbulkan kendala bagi pencipta untuk memiliki dan mendayagunakan hak ciptanya secara eksklusif dan melindungi hak tersebut dari pelanggaran hak oleh pihak lain.

Untuk itu perlu dilakukan suatu penelitian yang akan mengkaji masalah yang berkaitan dengan perlindungan hukum karya seni tradisional dan upaya-upaya peningkatan pemahaman dan kesadaran pencipta karya seni tradisional atas hak ciptanya guna menghindari eksploitasi oleh pihak lain yang tidak berhak. Sehingga dengan penelitian ini diharapkan adanya penghargaan terhadap pencipta karya seni tradisional melalui perolehan dan pemilikan haknya secara layak serta lebih lanjut akan berdampak lebih luas bagi penghargaan karya seni tradisional di dunia internasional. Dan lebih utama diharapkan dapat diciptakan iklim yang kondusif bagi kegiatan mencipta, sehingga secara stimulan dapat memberi pengaruh bagi tumbuh suburnya kreativitas masyarakat yang pada gilirannya dapat menciptakan stimulasi yang signifikan bagi lahirnya ciptaan-ciptaan baru yang beragam, berkualitas serta memberi manfaat bagi pengayaan khasanah kehidupan bangsa. ${ }^{1}$

\footnotetext{
1 Budi, Henry Soelistiyo. (2009). Sistem Perlindungan Hukum di Bidang Hak Cipta di Indonesia, Penelitian yang disampaikan pada Pelatihan HAKI bagi Dosen Fakultas Hukum Perguruan Tinggi Indonesia Bagian Timur, Surabaya. Hlm. 1.
} 


\section{B. Metode Penelitian}

Tujuan penelitian untuk mnjabarkan dan menganalisi Upayaupaya peningkatan pemahaman dan kesadaran pencipta karya seni tradisionil terhadap hak ciptanya.

Metode Penulisan menggunakan metode yuridis normatif.

Penelitian ini merupakan penelitian yang menggunakan pendekatan yuridis normatif yang mengkaji aspek hukum dari perlindungan karya seni tradisional menurut ketentuan normatif dan mengkaji aspek empiris dari upaya peningkatan pemahaman dan kesadaran pencipta atas hak ciptanya. Guna menunjang kajian tersebut, sumber data yang dipergunakan terdiri dari bahan hukum primer dan bahan hukum sekunder. Bahan hukum primer diperoleh dari peraturan perundangundangan di bidang hak cipta serta informasi dari pihak-pihak yang terkait. Sedangkan bahan hukum sekunder merupakan penunjang yang berupa berbagai macam bahan pustaka yang membahas hak cipta dan karya seni tradisional.

$\begin{array}{ccr}\text { Bahan } & \text { hukum } & \text { primer } \\ \text { dikumpulkan melalui } & \text { penelaahan }\end{array}$ peraturan perundangundangan yang berkaitan dengan permasalahan yang diteliti dan melalui teknik wawancara, sedangkan bahan hukum sekunder dikumpulkan dengan studi kepustakaan. Terhadap bahan-bahan hukum yang berhasil dikumpulkan dilakukan analisis secara kualitatif.

\section{PEMBAHASAN}

Sebelum dibahas mengenai perlindungan hukum karya seni tradisional dan upaya peningktan pemahaman dan kesadaran pencipta karya seni tradisional atas hak ciptanya, perlu dibahas apa yang dimaksud karya seni tradisioinal dan pencipta. Menurut hasil penelitian
Lembaga Ilmu Pengetahuan Indonesia (LIPI) karya seni tradisional diartikan sebagai pernyatan ekspresi estetika bangsa Indonesia yang khas dan asli yang secara sosial dipantulkan dala wujud yang nyata maupun hasil renungan dankreasi bangsa baik komunal maupun pribadi. ${ }^{2}$

Karya seni tradisional ini antara lain bisa berupa seni rupa (seni ukir, seni pahat, seni patung, seni lukis, kaligrafi), kerajinan tangan, seni Batik, seni tenun, seni pertunjukan (seni tari, seni musik, seni teater) dan seni arsitektur. Karya seni tradisional sebagai salah satu bentuk ciptaan masuk dalam lingkup perlindungan hak cipta, asalkan memenuhi kriteria atau syarat-syarat perlindungan hak cipta yaitu:

a. ciptaan tersebut merupakan ide yang telah selesai diwujudkan dalam bentuk yang khas dan dalam kesatuan yang nyata, sehingga dapat ditangkap oleh panca indera. Oleh karena itu ide, gagasan, citacita tanpa ada perwujudannya tidak dapat dilindungi hak cipta.

b. menunjukkan keaslian atau orisinalitas yang berarti ciptaan tersebut dihasilkan dari kemampuan pikiran, kreativitas, imajinasi, kecekatan, ketrampilan dan keahlian pencipta yang bersifat pribadi.

c. ciptaan tersebut dihasilkan dalam bidang ilmu pengetahuan, seni dan sastra.

Sedangkan yang dimaksud pencipta adalah seseorang atau beberapa orang secara bersama-sama yang atas inspirasinya lahir suatu ciptaan berdasarkan kemampuan pikiran, imajinasi, kecekatan, ketrampilan atau keahlian yang dituangkan dalam bentuk yang khas dan bersifat pribadi (pasal 1 angka 1

2 LKKN-LIPPI. 2009. Kapita Selekta Manifestasi Budaya Indonesia, Alumni, Bandung. Hlm. 107. 
UUHC 2002). Secara lebih rinci pencipta atau pemegang hak cipta karya seni tradisional dalam UUHC 2002 dapat dikategorikan sebagai berikut:

a. Untuk karya seni tradisional yang sudah jelas siapa penciptanya, maka pemegang hak cipta adalah pencipta yang jelas-jelas menghasilkan ciptaannya tersebut;

b. Untuk karya seni tradisional yang belum diketahui siapa penciptanya, maka pasal 10 A UUHC 2002 menetapkan :

$\begin{array}{lcr}\text { - apabila } & \text { suatu ciptaan } & \text { tidak } \\ \text { diketahui } & \text { penciptanya } & \text { dan } \\ \text { ciptaan } & \text { tersebut } & \text { belum } \\ \text { diterbitkan, } & \text { maka } & \text { negara }\end{array}$ memegang hak cipta atas ciptaan tersebut untuk kepentingan penciptanya.

- apabila ciptaan tidak diketahui penciptanya atau pada ciptaan tersebut hanya tertera nama samaran pencipta, makan penerbit yang memegang hak cipta atas ciptaan tersebut untuk kepentingan pencipta.

Pemegang hak cipta lebih terperinci lagi diatur dalam Undangundang Hak cipta No. 19 Tahun 2002 yang menetapkan ketentuan sebagai berikut:

a. Pada ceramah yang tidak tertulis dan tidak ada pemberitahuan siapa penciptanya, maka orang yang berceramah dianggap sebagai pencipta, kecuali terbukti sebaliknya [pasal 5 ayat (2)].

b. Jika ciptaan terdiri dari beberapa bagian tersendiri yang diciptakan dua orang atau lebih, maka yang dianggap sebagai pencipta adalah orang yang memimpin atau mengawasi penyelesaian seluruh ciptaan tersebut atau orang yang menghimpunnya dengan tidak mengurangi hak cipta masing- masing atas bagian ciptaannya (pasal 6 ).

c. Jika ciptaan dirancang seseorang, diwujudkan dan dikerjakan oleh orang lain di bawah pimpinan dan pengawasan orang yang merancang ciptaan, maka pencipta adalah orang yang merancang ciptaan tersebut (pasal 7).

d. Jika ciptaan dibuat dalam hubungan dinas dengan pihak lain dalam lingkungan pekerjaannya, maka pihak yang untuk dan dalam dinasnya ciptaan itu dikerjakan adalah pemegang hak cipta, kecuali ada perjanjian lain antara kedua pihak dengan tidak mengurangi hak si pembuat sebagai pencipta apabila penggunaan ciptaan itu diperluas ke luar hubungan dinas [pasal 8 ayat (1)].

e. Jika ciptaan dibuat dalam hubungan kerja dengan pihak lain, maka pihak yang membuat karya cipta itu sebagai pemegang hak cipta, kecuali diperjanjikan lain antara kedua pihak (pasal 8 ayat (2).

f. Jika suatu badan mengumumkan bahwa ciptaan berasal dari badan hukum tersebut dengan tidak menyebut seseorang sebagai pencipta, maka badan hukum tersebut dianggap sebagai pencipta kecuali jika terbukti sebaliknya (pasal 9).

g. Negara memegang hak cipta atas peninggalan prasejarah, sejarah dan benda budaya nasional lainnya [pasal 10 ayat (1)].

h. Negara memegang hak cipta atas ciptaan hasil kebudayaan rakyat yang menjadi milik bersama, jika berhubungan dengan pihak luar negeri [pasal 10 ayat (2b)].

i. Apabila suatu ciptaan sama sekali tidak diketahui siapa penciptanya, negara memegang hak cipta atas 
ciptaan tersebut kecuali terbukti sebaliknya (pasal 10 (A).

\section{A. Perlindungan Karya Seni \\ Tradisional}

1. Pemberian hak-hak kepada Pencipta

Pencipta karya seni tradisional mempunyai hak yang dinamakan hak moral (morale rights) dan hak ekonomi (economic rights). Hak moral adalah hak pencipta untuk mengklaim sebagai pencipta suatu ciptaan dan hak pencipta untuk mengajukan keberatan terhadap setiap perbuatan yang bermaksud mengubah, mengurangi atau menambah keaslian ciptaan yang dapat mengganggu kepentingan dan reputasi pencipta $^{3}$ serta merupakan hak yang kekal, selalu melekat pada pencipta dan tidak dapat dialihkan. ${ }^{4}$

Hak ekonomi merupakan hak pencipta untuk mendapatkan keuntungan atau mengeksploitasi ciptaan secara ekonomi.Hak ekonomi ini secara garis besar terdiri dari hak untuk mengumumkan dan memperbanyak ciptaannya. Meskipun pencipta karya seni tradisional mempunyai hak eksklusif atas ciptaannya, sistem hak cipta memperkenankan seseorang menggunakan ciptaan seseorang tanpa izin pencipta asalkan digunakan dalam batasbatas yang wajar (fair uselfair dealing) dengan syarat sumbernya harus disebut dengan

3 Damian, Eddy . (2007). Hukum Hak Cipta Menurut Beberapa Konvensi Internasional dan Undang Undang Hak Cipta 1997, Alumni, Bandung. Hlm. 62.

4 Djumhana, Muhammad. (2007). Hak Milik Intelektual; Sejarah, Teori dan Praktek di Indonesia, Citra Aditya Bhakti, Bandung. jelas dan dicantumkan serta tidak digunakan untuk tujuan komersial.

Dalam UUHC 2002 hal ini diatur dalam pasal 14: Dengan syarat bahwa sumbernya harus disebut atau dicantumkan maka tidak dianggap pelanggaran hak cipta :

a. Penggunaan ciptaan pihak lain untuk kepentingan pendidikan, penelitian, penulisan karya ilmiah, penyusunan laporan, penulisan kritik dan tinjauan suatu masalah dengan ketentuan tidak merugikan kepentingan yang wajar bagi pencipta.

b. Pengambilan ciptaan pihak lain baik seluruh atau sebagian guna keperluan pembelaan di dalam dan di luar pengadilan.

c. Pengambilan ciptaan pihak lain baik seluruh maupun sebagaian guan keperluan :

1. ceramah yang sematamata untuk tujuan pendidikan dan ilmu pengetahuan;

2. pertunjukan atau pementasan yang tidak dipungut biaya dengan ketentuan tidak merugikan kepentingan yang wajar bagi pencipta.

d. Perbanyakan suatu ciptaan bidang ilmu pengetahuan, seni dan sastra dalam huruf braile guna keperluan tuna netra, kecuali jika perbanyakan itu bersifat komersial.

e. Perbanyakan suatu ciptaan selain program, komputer secara terbatas dengan cara atau alat apapun atu proses serupa oleh perpustakaan 
umum, lembaga ilmu pengetahuan atau pendidikan dan pusat dokumentasi yang non komersial, semata-mata untuk keperluan akitvitasnya.

f. Perubahan yang dilakukan atas karya atsitektur seperti bangunan berdasarkan pertimbangan pelaksanaan teknis.

g. Pembuatan salian cadangan program komputer oleh pemilik program komputer yang dilakukan semata-mata untuk digunakan sendiri.

\section{Jangka Waktu Perlindungan}

Terhadap ciptaan yang memenuhi kriteria untuk diberi perlindungan, Undang undang Hak Cipta memberi jangka waktu perlindungan hak cipta dalam tiga kategori sebagaimana diatur pasal 26 dan pasal 27. Kategori pertama adalah untuk ciptaan yang sifatnya asli atau orisinil, jangka waktu perlindungan hukum diberikan selama seumur hidup pencipta ditambah 50 tahun setelah pencipta meninggal dunia untuk ciptaan :

a. buku, pamflet, dan semua hasil karya tulis lainnya

b. ceramah, kuliah, pidato dan ciptaan lainnya yang diwujudkan dengan cara diucapkan.

c. Alat peraga yang dibuat untuk keperluan pendidikan dan ilmu pengetahuan

d. Ciptaan lagu atau musik dengan atau tanpa teks termasuk karawitan.

e. Drama, tari(koreografi),pewayangan, pantomin.

f. Senirupa dalam segala bentuk seperti seni lukis, gmbar, seni ukir, seni kaligrafi, seni pahat, seni patung, kolase, seni terapan yang berupa kerajinan tangan;

g. Arsitektur

h. Peta.

i. Seni batik.

j. Terjemahan, tafsir, saduran, bunga rampai, dan karya lainnya dari hasil pengalih wujudan.

Sedangkan kategori kedua adalah untuk ciptaan yang bersifat turunan (derivatif) jangka waktu perlindungan diberikan hanya berlangsung 50 tahun sejak ciptaan yang bersangkutan diumumkan yaitu untuk ciptaan program komputer, sinematografi, rekaman suara, karya pertunjukan dan karya siaran.

Dan yang terakhir yaitu kategori ketiga untuk ciptaan berupa fotografi dan susunan perwajahan karya tulis yang diterbitkan sebagai buku jangka waktu perlindungan diberikan selama 25 tahun sejak pertama diumumkan.

\section{Perjanjian Lisensi}

Perjanjian lisensi

merupakan mekanisme lain perlindungan hukum karya seni tradisional. Perjanjian lisensi pada dasarnya hanya bersifat pemberian izin atau hak pencipta yang dituangkan dalam akta perjanjian untuk jangka waktu tertentu dengan syarat tertentu guna menikmati manfaat ekonomis suatu ciptaan yang dilindungi hak cipta. Dengan adanya perjanjian lisensi maka penggunaan hak ekonomis pencipta oleh orang lain dapat dipertanggungjawabkan secara legal. 
Untuk menjamin ketertiban dan kepastian hukum dan agar mempunyai akibat hukum bagi pihak ketiga, perjanjian lisensi wajib dicatatkan di kantor Hak Cipta (pasal 38 ayat (2) UUHC 2002) dan untuk dapat dicatatkan secara sah, perjanjian lisensi dilarang memuat ketentuan yang secara langsung maupun tidak langsung dapat menimbulkan akibat yang dapat merugikan perekonomian Indonesia (pasal 38 ayat (1) UUHC 2002).

\section{Upaya Hukum dalam Hal Terjadi Pelanggaran Hak}

Terhadap pelanggaran hak cipta atas karya seni tradisional dapat ditempuh upaya hukum melalui jalur perdata, pidan maupun hukum administrasi negara. Upaya hukum melalui jalur perdata didasarkan pada ketentuan pasal 41 yang memberikan hak dan kewenangan menggugat secara perdata pelanggaran hakhak moral pencipta dan juga ketentuan pasal 42 UUHC 2002 yang memberikan hak dan kewenangan menggugat pelanggaran hak-hak ekonomi pencipta.

Ketentuan pasal 42 UUHC 2002 memberikan hak kepada pemegang hak cipta untuk mengajukan gugatan ganti rugi, permohonan penyitaan barang-barang yang diduga merupakan hasil pelanggaran hak cipta, permohonan penyerahan seluruh atau sebagian penghasilan dari pelanggaran hak cipta, mengajukan permohonan penghentian kegiatan pembuatan, perbanyakan, penyiaran, pengedaran dan penjualan ciptaan atau barang yang merupakan hasil pelanggaran hak cipta.

Meskipun pemegang hak cipta dapat mengajukan gugatan ganti rugi secara perdata, gugatan ini tidak mengurangi hak negara untuk melakukan tuntutan pidana atas pelanggaran hak cipta. Hal ini disebabkan pelanggaran hak cipta tidak hanya merugikan pemegang hak cipt tetapi juga negara yang tidak mendapatkan pajak atas penjualan barangbarang pelanggaran tersebut. Untuk itu salah satu upaya menangkal pelanggaran hak cipta, undang-undang memberikan ancaman yang berat, sebagaimana diatur dalam pasal 44 UUHC 2002 :

a. Sanksi pidana 7(tujuh ) tahun dan atau denda paling banyak 100 (seratus) juta rupiah bagi yang sengaja dan atau tanpa hak mengumumkan atau memperbanyak ciptaan atau memberi izin untuk itu.

b. Sanksi pidana 5 (lima ) tahun dan atau denda paling banyak 50 (limapuluh) juta rupiah bagi yang sengaja menyiarkan, memamerkan atau mengedarkan atau menjual kepada umum suatu ciptaan atau barang hasil pelanggaran hak cipta.

c. Sanksi pidan 3 (tiga ) tahun dan atau denda 25 (duapuluh lima) juta rupiah bagi yang sengaja melanggar larangan pemerinta mengumumkan hasil ciptaannya.

d. Sanksi pidana 2(dua ) tahun dan atau denda 15 (lima belas) juta rupiah bagi pemegang hak cipta yang mengumumkan dan memperbanyak ciptaan potet tanpa seizin yang dipotret. 
Tindak pidana pelanggaran hak cipta semula merupakan delik aduan, namun dengan undang-undang yang baru dirubah menjadi delik biasa. Dan agar supaya dapat menangani substansi pelanggaran hak cipta secara tepat, proses penyidikan pelanggaran hak cipta dilakukan Penyidik Pelanggaran Hak Cipta yang dilakukan oleh Pejabat Pegawai Negeri Sipil (PPNS) di lingkungan Departemen Kehakiman (sekarang Departemen Hukum dan Perundangundangan) yaitu PPNS Hak Cipta tingkat Kanwil dan PPNS Hak Cipta tingkat Nasional (PPNS Dirjen HAKI). Hasil penyidikan PPNS Hak Cipta akan diserahkan ke Penyidik Kepolisian dan Penuntut Umum.

Selain upaya perdata dan pidana, terhadap pelanggaran hak cipta dapat ditempuh upaya melalui jalur administrasi negara yang mempunyai kewenangan di bidang kepabeanan dengan mendasarkan pada undangundang No. 10 Tahun 1995 tentang Kepabeanan khususnya Bab X yang berisi Larangan Pembatasan Impor dan Ekspor serta Penggendalian Impor dan Ekspor Barang Hasil Pelanggaran Hak atas Kekayaan Intelektual.

\footnotetext{
Pelaksana kewenangan ini dilakukan oleh Dirjen Bea dan Cukai yang mempunyai kewenangan yang bersifat pasif untuk menangguhkan sementara waktu pengeluaran barang impor atau ekspor dari kawasan kepabeanan yang berdasarkan bukti yang cukup diduga merupakan hasil pelanggaran hak cipta (pasal 54 UU No. 10 tahun 1995) . Kewengan Bea cukai ini bersifat pasif karena kewenangan
}

tersebut hanya dilaksanakan jika ada permohonan dari pemegang hak cipta kepada pengadilan negeri yang daerah hukumnya meliputi wilayah kepabeanan tempat ekspor atau impor berlangsung.

\section{B. Upaya Upaya Peningkatan Pemahaman Dan Kesadaran Pencipta Atas Hak Ciptanya}

\begin{tabular}{llr}
\multicolumn{1}{c}{ Secara } & umum pemerintah \\
mempunyai & prioritas & untuk \\
meningkatkan & pemahaman & dan
\end{tabular} kesadaran masyarakat mengenai Hak Atas Kekayaan Intelektual (HAKI) melalui beberapa upaya. Pemerintah tersebut selain melalui penyuluhan, diskusi, seminar, dan lokakarya, ditempuh pula upaya strategis melalui perguruan tinggi untuk mengajarkan HAKI sebagai bagian pengetahuan yang baru dan penting untuk diajarkan guna mempersiapkan para lulusan perguruan tinggi untuk memililiki bekal pengetahuan tentang HAKI yang nantinya akan ditularkan kepada masyarakat tempat lulusan tersebut terjun beraktivitas.

Upaya konkrit lain dilakukan melalui penyelenggaraan pelatihan yang dipusatkan di Universitas Indonesia untuk kawasan barat Indonesia dan Universitas Airlangga untuk kawasan timur Indonesia. Di Universitas Airlangga pelatihan HAKI diselenggarakan dengan bekerjasama dengan Pemerintah Australia dan sudah berlangsung untuk 4 angkatan sampai dengan Februari 1999, bahkan beberapa dosen dan praktisi dari berbagai bidang asal Indonesia dikirim ke Australia untuk mendapat pelatihan HAKI atas biaya Pemerintah Australia.

Secara kelembagaan pemerintah membentuk Tim Keppres 34 yang 
mempunyai tugas untuk membenahi ketentuan-ketentuan HAKI dan mengkoordinir keterpaduan gerak dan langkah dalam upaya pencegahan dan penanggulangan pelanggaran di bidang HAKI. Tim Keppres ini yang membidangi beberapa pelatihan di bidang HAKI guna menyamakan persepsi.meningkatan pemahaman dan ketrampilan aparat penegak hukum dan masyarakat dalam menganggapi masalah HAKI. Selain itu pemerintah juga telah membentuk Dewan Hak Cipta yang mempunyai tugas untuk membantu pemerintah dalam memberikan penyuluhan, bimbingan dan pembinaan Hak cipta.

Selain upaya yang dilakukan oleh pemerintah, terdapat pula beberapa upaya yang dilakukan beberapa kelompok masyarakat untuk meningkatkan pemahaman dan sosialisasi HAKI seperti pembentukan Perhimpunan Masyarakat HAKI (Indonesia Intellectual Property Society disingkat IIPS) yang mempunyai motto "menyebarluaskan pemahaman HAKI mепији masyarakat Indonesia yang inovatif dan kreatif". Kegiatan untuk menyebarluaskan pemahaman HAKI oleh IIPS dilakukan antara lain melalui pendidikan dan latihan yang pada tahun 1999 dilakukan Diklat HAKI di Mabes Polri, diterbitkan buletin HAKI untuk referensi bagi pemerhati dan pihak yang berkepentingan dengan HAKI, juga dilakukan seminar dan simposium.

Seminar yang dilakukan yang berhubungan dengan karya seni tradisional adalah Serial Seminar Seni Pertunjukan Indonesia yang diadakan di Solo pada tanggal 19 sampai 20 Februari 2009. Seminar yang menghadirkan seniman $\mathrm{Ki}$ Dalang Sumartono ini menghasilkan kesimpulan bahwa belum terciptanya iklim yang kondusif bagi perlindungan karya seni tradisional bukan disebabkan instrumen perlindungan hukum yang kurang, tetapi terutama juga karena kesadaran pelaku seni yang masih kurang, sehingga perlu dilakukan upaya yang lebih intensif untuk meningkatkan pemahaman dan kesadaran pendipta karya seni tradisional.

\section{PENUTUP}

\section{A. Kesimpulan}

Dalam penelitian ini diambil suatu kesimpulan bahwa perlindungan hukum karya seni tradisional masuk dalam lingkup perlindungan hak cipta yang secara garis besar meliputi pemberian hak-hak kepada pencipta, pemberian jangka waktu perlindungan hukum yang cukup lama, perjanjian lisensi serta upaya upaya hukum yang dapat ditempuh dalam hal terjadi pelanggaran baik itu melalui jalur perdata, pidana maupun administrasi negara.

Sedangkan upaya peningkatan pemahaman dan kesadaran pencipta atas hak ciptanya dilakukan melalui upaya sosialisasi HAKI seperti penyuluhan, diskusi, seminar, lokakarya, simposium, pendidikan dan pelatihan HAKI serta secara kelembagaan pemerintah telah membentuk Dewan Hak Cipta. Pada akhirnya disarankan agar pengaturan mengenai perlindungan hukum hak cipta khususnya hak cipta karya seni tradisional perlu diiringi penegakan hukum yang konsisten dan upaya peningkatan pemahaman dan kesadaran pencipta atas hak ciptanya perlu lebih diintensifkan baik dari segi kualitas maupun kuantitas. 
Nina Yolanda, Upaya-Upaya Peningkatan Pemahaman Dan Kesadaran Pencipta Karya Seni Tradisional Terhadap Hak Ciptanya, Halaman 32-41

\section{B. Saran}

Sebaiknya setiap pelanggaran atau kejahatan terhadap Hak Cipta Seseorang diberikan ganjaran hukuman untuk memberikan efek jerah terhadap orang yang telah mengambil Hak Cipta Seseorang. Oleh karena itu Pemerintah harus bertindak tegas setiap kejahatan terhadap Hak Cipta yang telah dimiliki oleh sipencipta.

\section{DAFTAR PUSTAKA}

Budi, Henry Soelistiyo. (2009). Sistem Perlindungan Hukum di Bidang Hak Cipta di Indonesia, Penelitian yang disampaikan pada Pelatihan HAKI bagi Dosen Fakultas Hukum Perguruan Tinggi Indonesia Bagian Timur, Surabaya.

Damian, Eddy . (2007). Hukum Hak Cipta Menurut Beberapa Konvensi Internasional dan Undangundang Hak Cipta 1997, Alumni, Bandung.

Djumhana, Muhammad. (2007). Hak Milik Intelektual; Sejarah, Teori dan Praktek di Indonesia, Citra Aditya Bhakti, Bandung.

LKKN-LIPPI. 2009. Kapita Selekta Manifestasi Budaya Indonesia, Alumni, Bandung

Maulana, Insan Budi. (2007). Sukses Bisnis Melalui Merek, Paten dan Hak Cipta, Citra Aditya Bhakti, Bandung.

Saidin . (2007). Aspek Hukum Hak Kekayaan Intelektual, Raja Grafindo, Jakarta.

Torn, Eric A. (2009). Understanding Copyrights-a Practical Guide, London. 